
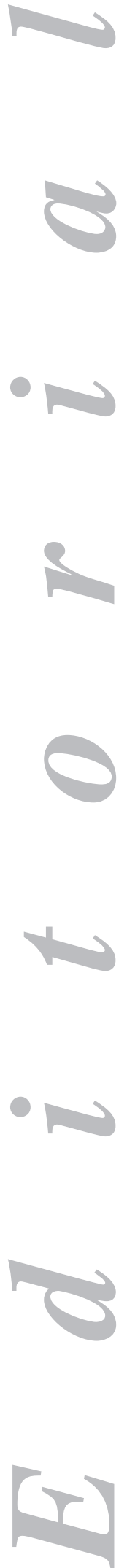

\section{Prevalence of hepatitis B and C in Spain - further data are needed}

Chronic infection with hepatitis $\mathrm{B}(\mathrm{HBV})$ and $\mathrm{C}(\mathrm{HCV})$ viruses is a public health issue worldwide. The prevalence of HBV infection reported by the World Health Organization (WHO) in its last update of July 2013 is 2 billion, of which over 240 million people (5\% of the general population) have chronic hepatitis (1). Overall HCV prevalence is lower, with estimates around 150 to 170 million people (3\% of the general population) and an annual incidence of up to 3-4 million new cases (2). Furthermore, WHO reported that the number of deaths associated with liver cirrhosis, liver-cell carcinoma, and liver failure is higher than 600,000 yearly for HBV and over 350,000 yearly for HCV (1-3). Primary transmission routes for both viruses include: a) blood transfusion (before 1992 for $\mathrm{HCV}$ ); b) parenteral or non-parenteral drug use; c) tattoos and piercings performed with inadequate hygiene conditions; d) perinatal transmission (particularly for HBV in countries with no adequate prophylaxis); e) sexual transmission (less common for $\mathrm{HCV}$ ); and $\mathrm{f}$ ) nosocomial transmission.

The geographical distribution of these viral infections is universal, even though their prevalence varies among countries according to controls exerted on transmission mechanisms and extent of HBV immunization. Hepatitis B is considered an endemic condition with prevalences of 10-20\% in regions such as Southeast Asia, China, SubSaharan Africa, and India, where most infections occur during childhood. In Western Europe and North America the population with chronic HCV infection remains below $1 \%$. The highest rates of chronic infection with HCV are found in Egypt (15\%), Pakistan (4.8\%) and China (3.2\%), the primary risk factor being injections with contaminated material. The prevalence of $\mathrm{HCV}$ in the various European countries ranges from 0.1 to $5 \%$ (4).

In this issue of Revista Española de Enfermedades Digestivas, Calleja Panero et al. (4) discuss the prevalence of HBV- and HCV-related serum markers in a healthy employed population of Murcia and Madrid. This study of 5017 volunteers has three interesting contributions: first, a prevalence lower than described in prior papers $(0.7 \%$ for $\mathrm{HBV}$ and $0.6 \%$ for $\mathrm{HCV}$ ); second, the AgHBs-positive population had normal transaminase values, albeit with a slight increase in AST, whereas the anti-VHCpositive population had transaminase and GGT levels above normal; finally, the predominant infection mechanisms shared by both diseases included prior blood transfusion, presence of tattoos, and living with infected individuals. IV drug use only was a risk factor for $\mathrm{HCV}$ infection. Hospitalization was not associated with increased infection rates.

As regards the prevalence of HBV infection, Spain is considered an intermediateprevalence country by WHO (2-8\%), consistent with the rest of Mediterranean countries. However, studies recently reported suggest a considerable reduction, with a prevalence between $0.27 \%$ and $1.69 \%$ (Table I). For HCV, the prevalence of antibodies 
against this virus oscillates between $1.6 \%$ and $2.6 \%$ in the general population. Also, the prevalence of serum markers is dependent on age and region under study. The prevalence of $\mathrm{HCV}$ infection in children and adolescents falls between $0 \%$ and $0.7 \%$ (5-7), and ascends to $3.1-5.5 \%$ in adults older than 60 years $(8,9)$. Table I includes a view of the geographical distribution of HBV and HCV prevalence in Spain.

In contrast to HBV, no preventive immunization is available for HCV. In Spain, since the late 1990s, all Autonomous Communities systematically immunize newborns against HBV. Interestingly, universal immunization, systematic blood donation control, and serum screening during the third trimester of pregnancy have contributed to a decreased incidence and mortality in Spain during the last few years (1997-2005); however, these parameters have shown an upturn from 2005 onwards, as is also the case in the rest of Europe (10). This event has been attributed to increasing immigrant populations from regions with a high prevalence, changing social behaviours, and refined case reporting and diagnostic techniques. To this also point out the data reported by 'Red Nacional de Vigilancia Epidemiológica', which suggest a gradual reduction in the prevalence of HCV in Spain in the past few years. This reduction may be attributed to a better understanding of the disease and a decrease in some risk factors, including syringe sharing and systematic blood donation control. In contrast with the general consensus on the increasing influence of immigration on HBV prevalence in both Spain and Europe, the study by Calleja Panero et al. does not confirm such association. Similarly, healthcare and public health staff usually in contact with blood is a most relevant group at risk for hepatitis B infection, a circumstance not discussed in the above-mentioned paper. As regards the prevalence of $\mathrm{HCV}$ in the immigrant population, it is very low among Latin Americans, relatively low in Eastern Europeans, and high among Asians and Sub-Saharans. Therefore, their influence in the prevalence of the general population depends on their origin and varies considerably from one Spanish region to the next. The above study finds no significant association between $\mathrm{HCV}$ prevalence and immigration. While no data are provided on immigration origin, the fact that this is a selected population is highlighted, as most are workers with a residence permit and, perhaps most relevant of all, younger than the general population studied. Lastly, a set of recommendations for improved hepatitis B management in

Table I. Prevalence of HCV and HBV serum markers in Spain

\begin{tabular}{lllll}
\hline Region & No. of cases & Anti-HCV (\%) & AgHBs (\%) & Publication \\
\hline Rioja & 890 & 2 & & $1996(8)$ \\
Madrid & 1,109 & 2.5 & 1.2 & $1997(15)$ \\
Gijón & 453 & 1.76 & & $1997(16)$ \\
Asturias* & 1,170 & 1.6 & 1.69 & $2001(17)$ \\
Catalonia & 2,194 & 2.6 & & $2002(9)$ \\
Zamora & 675 & 0.74 & 0.8 & $2002(18)$ \\
Granada & & & & $2005(12)$ \\
pregnant women) & 381 & 0.5 & $<0.27 ; 8.2 * * *$ & $2007(20)$ \\
Madrid** & 651 & 46 & $0.7 ; 8.7 * * *$ & $2007(21)$ \\
Castile \& Leon & 364 & 1.1 & & $2009(22)$ \\
Catalonia & 2,620 & & 0.7 & $2013(4)$ \\
Andalusia** & 1,468 & 16 & & \\
Madrid/Murcia* & 5,017 & 0.6 & &
\end{tabular}

*Healthy employed population; **HIV-positive patients; ***Anti-HBC. 
Spain, published by an expert group, should be underscored. These include immunization program maintenance (with a special focus on the coverage and screening of foreign populations), improved information on $\mathrm{HBV}$ prevention, detection and treatment in the general population, and above all among health care professionals, and enhanced research on prevention and innovating therapies (11).

On the other hand a number of interesting studies on viral hepatitis during pregnancy have been carried out. Regarding HBV, the prevalence for pregnant women in our setting is around $0.8 \%$ and, as with $\mathrm{HCV}$, vertical transmission (VT) is a most important mechanism of infection (12). In our country, post-exposure prophylaxis is used for children, but this may not suffice at present. In a recent paper on an Asian population, approximately $10 \%$ of children born to AgHBe-positive mothers with a high viral load (7-8 $\log _{10}$ copies/ml) had chronic HBV infection despite adequate prophylaxis. This shows the relevance of antiviral use in mothers with a high viral load during the third trimester of pregnancy (13). The prevalence of $\mathrm{HCV}$ in pregnant women is similar to that of general population (0.53-1.4\%) (12). While HCV VT and chronification rates are low (around 5\%), 90\% of infected children are known to have acquired this virus through this route (14). Factors involved in HCV VT are unknown in most cases. However, presumed potential risk factors include a high viral load at birth and coinfection with HIV (20-30\%). As our knowledge increases regarding HCV and the significance of host-related immunogenetic factors, and most particularly with the development of peg-interferon-free and ribavirin-free (contraindicated during pregnancy) antiviral agents directly targeting the virus, we shall be able to gain a deeper insight on said factors and to prophylactically approach VT.

Finally, further studies are needed to update prevalence data with new social trends, migratory changes, novel treatments, and current prevention strategies in mind. Similarly, studies should focus on the general population, since most data on the prevalence of infection with the aforementioned viruses were obtained from high-risk populations not representative of the prevalence of HBV and HCV infection in Spain.

José Antonio Muñoz-Gámez and Javier Salmerón

Unit of Digestive Diseases. Hospital Universitario San Cecilio. CIBERehd. Granada, Spain

\section{REFERENCES}

1. http://www.who.int/mediacentre/factsheets/fs204/en/

2. http://www.who.int/mediacentre/factsheets/fs164/en/

3. Cobb B, Pockros PJ, Vilchez RA, Vierling JM. HCV RNA viral load assessments in the era of direct-acting antivirals. Am J Gastroenterol 2013;108:471-5.

4. Calleja Panero JL, Llop Herrera E, Ruiz Moraga M, de la Revilla Negro J, Calvo Bonacho E, Pons Renedo F, et al. Prevalence of viral hepatitis (Band C) serological warkers in healthy working population. Rev Esp Enferm Dig 2013;105:249-54.

5. Montes Martinez I, Agulla Budino A. Prevalence of antibodies against hepatitis A, B, C and E viruses in the rural child population in Northern Extremadura. An Esp Pediatr 1996;45:133-6.

6. Gil Miguel A, Ruedas A, Santos Santos M, Rey Calero YJ. Prevalence of hepatitis C virus infection in school children in an urban and suburban area of Madrid. Aten Primaria 1996;17:521-2.

7. Martínez Pérez JA, Gomeno Fernández C, González Praetorius A, Gascuena Luengo M, Calvo Orduna MJ, Caballero Moreno L. Seroprevalence of three types of hepatotropic virus in a population of adolescents of the province of Guadalajara. Rev Esp Salud Pública 2001;75:151-7.

8. Sacristan B, Gastanares MI, Elena A, Sacristan M, Barcenilla J, García JC, et al. Seroepidemiologic study of hepatitis $\mathrm{C}$ virus infection in a general population from the region of La Rioja, Spain. Med Clin (Barc) 1996;107:331-5. 
9. Sola R, Cruz de Castro E, Hombrados M, Planas R, Coll S, Jardi R, et al. Prevalence of hepatitis B and hepatitis C viruses in different counties of Catalonia, Spain: cross-sectional study. Med Clin (Barc) 2002;119:90-5.

10. Hernando Sebastián M, Soler Crespo P, Garrido Estepa M, Cano Portero R, Llácer Gil de Ramales A. Vigilancia epidemiológica de la Hepatitis B en España. Años 1997-2008. Boletín epidemiológico semanal, 18 oct 2010.

11. Grupo de Estudio de la Hepatitis B (GEsHeB). Orientaciones para un mejor manejo de la hepatitis B en España. Rev Esp Sani Penit 2009;11:87-95.

12. Ruiz-Extremera A, López-Garrido MA, Barranco E, Quintero MD, Ocete-Hita E, Muñoz de Rueda P, et al Activity of hepatic enzymes from week sixteen of pregnancy. Am J Obstet Gynecol 2005;193:2010-6.

13. Wen WH, Chang MH, Zhao LL, Ni YH, Hsu HY, Wu JF, et al. Mother-to-infant transmission of hepatitis B virus infection: Significance of maternal viral load and strategies for intervention. J Hepatol 2013;59:24-30.

14. Ruiz-Extremera A, Munoz-Gámez JA, Salmerón-Ruiz MA, de Rueda PM, Quiles-Pérez R, Gila-Medina A, et al. Genetic variation in interleukin 28B with respect to vertical transmission of hepatitis $\mathrm{C}$ virus and spontaneous clearance in HCV-infected children. Hepatology 2011;53:1830-8.

15. Prieto Domingo JJ, Carrión Bolanos JA, Brandes Moya F. Prevalence of hepatitis C virus and excessive consumption of alcohol in a nonhospital worker population. Gastroenterol Hepatol 1997;20:479-83.

16. Suárez A, Viejo G, Navascués CA, García R, Díaz G, Saro C, et al. The prevalence of hepatitis A, B and C viral markers in the population of Gijón between 26 and 65 years old. Gastroenterol Hepatol 1997;20:347-52.

17. Riestra S, Fernández E, Leiva P, Garcia S, Ocio G, Rodrigo L. Prevalence of hepatitis C virus infection in the general population of northern Spain. Eur J Gastroenterol Hepatol 2001;13:477-81.

18. Chimeno MM, Chocarro A, Brezmes P, Ochoa C, Perez J. Seroprevalence of hepatitis C virus in the general population. Enferm Infecc Microbiol Clin 2002;20:64-7.

19. González Cerrajero M, Pazos García A, de los Santos Gil I, Sanz Sanz J. An Med Interna. Prevalence of hepatitis C virus among HIV-infected patients in Area 2 of Madrid 2006;23:111-4.

20. López-Izquierdo R, Udaondo MA, Zarzosa P, García-Ramón E, Garcinuño S, Bratos MA, et al. Seroprevalence of viral hepatitis in a representative general population of an urban public health area in Castilla y Leon (Spain). Enferm Infecc Microbiol Clin 2007:25:317-23.

21. Salleras L, Domínguez A, Bruguera M, Plans P, Costa J, Cardeñosa N, et al. Declining prevalence of hepatitis $\mathrm{B}$ virus infection in Catalonia (Spain) 12 years after the introduction of universal vaccination. Vaccine 2007;25:8726-31.

22. Palacios R, Mata R, Aguilar I, Munoz L, Ríos MJ, Vergara S, et al. High seroprevalence but low incidence of HCV infection in a cohort of patients with sexually transmitted HIV in Andalusia, Spain. J Int Assoc Physicians AIDS Care 2009;8:100-5 